\title{
Torakolomber omurga kırıkları: toplumsal ve ekonomik bakış açısı
}

\section{Thoracolumbar spine fractures: social and economic perspective}

\author{
Ömer Akçalı
}

Dokuz Eylül Üniversite Hastanesi, Ortopedi ve Travmatoloji Anabilim Dalı, İzmir

\begin{abstract}
Omurga kırıkları, sanayileşmenin artmasına paralel olarak artan oranlarda karşımıza çıkmaktadır. Omurga vücudumuzun derin kısımlarında yerleşen bir kemik yapı olduğu için kırık yaratacak travmalar yüksek enerjili travmalar olmak zorundadır. Omurga kırıkları, ülkemiz için mevsimsel ve bölgesel özellikler gösterir. Trafik kazalarının yanında yüksekten düşmeler de sık görülen nedenler arasındadır. Spinal kord yaralanması olan hasta çoğunlukla kendisini toplumdan dişlar ve bunun sonucunda ciddi depresyon tabloları görülür. Medikal tedavinin yanında psikolojik destek gerekir. Omurga kırıklarının tedavisi oldukça yüksek maliyet gerektirir. Nörolojik yaralanması olmayan torakolomber kırıklarda cerrahi tedavilerin maliyet-etkinlik oranları konservatif yöntemlere göre daha kötü gibi durmaktadır.
\end{abstract}

Anahtar sözcükler: omurga kırığı; maliyet-etkinlik; cerrahi tedavi; nörolojik yaralanma; toplumsal etki
Thoracolumbar spine fracture ratios are increasing in parallel with the growth of industrialization. Since the spinal column is located in the deep layers of human body, traumas that affect the spine should have to be high energy traumas. In our country, spinal fractures present regional and seasonal particularities. Besides the traffic accidents, falling from high altitude is also a common cause. The patients with spinal cord injuries often externalize themselves from the community and serious depression cases are common. Psychological support is indicated in addition to medical treatment. Economic burdens of the treatment of spine fractures are significant. As compared with the conservative measures, cost effectiveness of surgical treatment is not better in thoracolumbar fractures with neurologic deficit.

Key words: spine fractures; cost effectiveness; surgery; neurologic damage; social effects

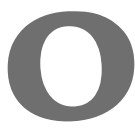
murga kırıkları, sanayileşmenin artmasına paralel olarak ortaya çıkan travmatik faktörlerin etkisi ile, gittikçe artan oranlarda karşımıza çıkmaktadır. Motorlu taşıtların ve trafiğin artması, beraberinde omurga kırıklı trafik kazalarını da yaygınlaştırmıştır. Günümüzde, trafikteki araçların birçoğu yüksek hızlara çıkabilmektedir. Araçları hızlandırmada elde edilen "başarı" aynı aracın durmasını sağlayan donanım ve asfalt ile uyuşmayınca da yüksek enerjili trafik kazaları oluşmaktadır. Omurga vücudumuzun derin kısımlarında yerleşen bir kemik yapı olduğu için, osteoporotik hastalar hariç olmak üzere, omurgada kırık yaratacak travmalar yüksek enerjili travmalar olmak zorundadır. Benzer şekilde; inşaat sektöründeki teknik ilerlemeler sonucu bina yükseklikleri artmakta, ancak çalışanların güvenliğine yönelik önlemler bu yükselmelerin gerisinde kalmaktadır. Sonuçta da, yüksek enerjili travmalar ve bu travmalarla oluşan yaralanmaların görülme sıklıkları da artmaktadır.

Omurga kırıkları, ülkemiz için mevsimsel ve bölgesel özellikler gösterir. Yaz aylarında sığ suya dalma ve yüksekten düşme tarzında travmalar sık görülür. Ege bölgesinde, sonbahar aylarında zeytincilik nedeniyle yüksekten düşmeler çoğalırken, kuzey bölgelere gidildikçe fıstık çamı işçilerinde yaz ve sonbahar aylarında yüksekten düşmeler sıkça görülür. Motorlu taşıt kazaları da yaz aylarında ve tatil günlerinde artış göstermektedir. Özellikle motosiklet kazaları torakolomber omurga yaralanmaları açısından ciddi risk oluşturmaktadır. Büyük şehirlerin şehir merkezleri ve şehirlerarası otoyollar, omurga kırıklı trafik kazalarının sıkça oluştuğu yerlerdir.

- Illetişim adresi: Prof. Dr. Ömer Akçalı, Dokuz Eylül Üniversite Hastanesi, Ortopedi ve Travmatoloji Anabilim Dalı, Balçova, İzmir Tel: 0533 - 7157086 e-posta: omer.akcali@deu.edu.tr, omerakcali@gmail.com

- Geliș tarihi: 1 Kasım 2018 Kabul tarihi: 1 Kasım 2018 
Omurga kırıklarının toplumsal yönden önemli bir diğer yönü de spinal kord yaralanmasıdır. Torakolomber bileşke kırıklarında, hastaların yarısında spinal kord hasarı görüldüğü bildirilmektedir. ${ }^{[1,2]}$ Omurga kırıklarının en sık görüldüğü bölgenin de torakolomber bileşke olduğu göz önünde bulundurulursa, nörolojik hasar riskinin ne kadar yüksek olduğu ortadadır. Nörolojik defisit parsiyel olabilir ve hastanın günlük yaşamını çok etkilemeyebilir. Ancak pratikte, total nörolojik kayıplar genellikle daha sık görülür. Total nörolojik yaralanmanın özellikleri ve tedavisi ilerleyen bölümlerde anlatılmıştır. Her ne kadar rehabilitasyon yöntemlerinde ilerlemelere paralel olarak hastalar cihazlarla mobilize olsalar da, spinal kord yaralanması olan bir hasta çoğu zaman kendisini toplumdan dışlar. Başlangıçta inkâr ve yadsıma mekanizmaları ile içinde bulunduğu durumu kabullenmez. Bir süre sonra, gelecekte bulunabilecek tedavilerle ayağa kalkabilecekleri düşüncesi ile hekim ve yöntem arayışına girer. Bunu, sosyal medyadaki çözüm arayışları takip eder ve yaklaşık bir yıl civarında bir süre sonunda da içinde bulunduğu durumu kabullenme davranışı gözlenir. Bu süreç içerisinde, aile içi sorunlar ve ayrılıklar yaşanabilir. Hastalar kendilerini derin boşluklar içinde hissederler ve spinal kord yaralanmalı hastaların büyük kısmında bu dönemlerde ciddi depresyon tabloları görülür. Medikal tedavinin yanında psikolojik destek de gerekir.

Torakolomber omurga kırıkları ekonomik açıdan da önem taşır. Gerek cerrahi gerekse konservatif tedavileri yüksek maliyetlere sahiptir. Birleşik Amerika'da yapılan bir çalışmada, 25 yaş civarında nörolojik yaralanmalı bir omurga kırığı hastasının yaşamı boyunca sağlık giderlerinin ortalama 2,7 milyon dolar olacağı bildirilmiştir. ${ }^{[3]}$ Ülkemizde maliyete yönelik olarak ayrıntıI çalışmalar ne yazık ki çok fazla değildir. Ancak, bizim kendi kliniğimizdeki 30 yıla yakın deneyimimizde, cerrahi ve konservatif yöntemlerle tedavi edilen hastalardaki tedavi maliyetimiz göz önüne alındığında, ekonomik olarak önemli rakamlar ortaya çıkmaktadır. Tedavi maliyetlerine cerrahi ve konservatif yöntemleri ayırarak bakacak olursak, hastaların nörolojik tablolarına göre farklı sonuçlar ortaya çıkmaktadır. Nörolojik yaralanması olmayan hastalarda cerrahi tedavi maliyetleri konservatif yöntemlere göre daha yüksektir. Klinik sonuçlarla karşılaştırıldığında ise nörolojik yaralanması olmayan torakolomber burst kırıklarında cerrahi tedavinin maliyet/klinik yarar açısından dezavantajlı olduğu öne sürülmüştür. ${ }^{[2]}$ Bununla birlikte, nörolojik yaralanması olan hastalarda her ne kadar cerrahi dekompresyonun klinik düzelmeye etkisi ortaya konamamış olsa da, ülkemize özgü olarak, medikolegal sorunlarla karşılaşmamak için bir alternatif olarak göz önünde bulundurulması gerektiği kabul edilebilir.

Sonuç olarak, torakolomber omurga kırıkları halk sağlığı ve sağlık harcamaları açısından önemli yaralanmalardır. Önlenebilir olmasının yanında, tedaviye yönelik rasyonel ve akılcı tedavi algoritmaları ile nörolojik yaralanmalı bireyler toplumsal yaşam içine alınabilir; üretime katkıları daha fazla olabileceği gibi sağlık harcamaları da azaltılabilir.

\section{KAYNAKLAR}

1. Tang P, Long A, Shi T, Zhang Licheng, Zhang Lihai. Analysis of the independent risk factors of neurologic deficit after thoracolumbar burst fracture. J Orthop Surg Res 2016;11(1):128. Crossref

2. Aras EL, Bunger C, Hansen ES, Søgaard R. Cost-Effectiveness of Surgical Versus Conservative Treatment for Thoracolumbar Burst Fractures. Spine (Phila Pa 1976) 2016;41(4):337-43. Crossref

3. Chan BCF, Craven BC, Furlan JC. A scoping review on health economics in neurosurgery for acute spine trauma. Neurosurg Focus 2018;44(5):E15. Crossref 